\title{
DEVELOPMENT OF PROFESSIONAL COMPETENCIES WITHIN THE FURTHER EDUCATION OF DANCE TEACHERS
}

\section{Summary}

\section{Introduction}

The perfection of the competencies as integrative pedagogical category in the education of the dance teachers is an innovative approach to the common social-cultural space. As perceived by the authors of the article, the competencies of the dance teachers in their objective contents' structure arise from their individual experience and the opportunities of gaining the experience by life action.

\section{Aim of the Study}

To establish the dance teachers' competences and to construct a model for the further education of the dance teachers on the basis of the theoretical and empirical research.

\section{Materials and Methods}

Theoretical methods (the analysis and modelling of the professional competencies of the dance teachers) and the empirical (survey analyses and processing) research methods have been implemented in the research.

\section{Results}

Theoretically based dance teacher competency development model for the further education is worked out.

\section{Conclusions}

The dance teacher professional competencies' subject content structure is constructed by two components- the subjective and the objective - correlation, which is based on the basic principles of the further education (self-experience, other experience, the world experience) and is implemented by the continuous life-long education.

Key words: competencies, the further education of the dance teachers, principles, a model.

\section{Introduction}

Nowadays the competence in pedagogy is defined as a set of abilities, which can be acquired by life-action by continuous perfection. This explanation is based on opinions of the action theory, which emphasize the objective and mental unity of cognition. Therefore, the competence has to be dealt with from both the subjective (abilities, experience) and the objective (opportunities of the experience acquisition) aspect. I. Tilla claims that the subject-content structure of the competency is formed by correlation of two components - the subjective and the objective. The first component involves the abilities substantiated by the individual experience, the second - the opportunities gained by the self-experience, the experience of others and the world. Such an approach to the explanation of the competence points out that an individual encounters ever new opportunities to continuous perfection of the experience, by life-long developing of them. Andreas Bruck analyzes the competence as a result and constructs characteristics of a competent person $-\mathrm{s} /$ he is able to realize his/her set intention, s/he has knowledge and skills to implement the intention, s/he can 
successfully organize the action in new complicated situations (Bruck, 2000). By analyzing the competence as an action and also as a result I. Tilla forms a definition of the competence: it “...is an individual combination of abilities and experience based on opportunities of gaining experience. In the procedural comprehension it is continuously perfected, as the abilities are developed life-long, the experience is perfected and new opportunities for gaining the experience arise continuously. The competence as a result is revealed in the quality level of the action of the specific situation" (Tillıa, 2005). Also the European Commission Memorandum of 30 October, 2000 of life-long learning has encouraged many states and their science industries to assess the opportunities of lifelong education. The perfection of the competency as integrative pedagogical category in education of the dance teachers is an innovative approach in the common social-cultural space. As perceived by the authors of the article,the subject-content structure of the competency of the dance teachers is based on interrelation provided by their individual experience and the opportunities of gaining the experience by life action (Gilbert, 2005).

\section{Aims of the Study}

To substantiate the dance teachers' competencies and to construct a model for further education of the dance teachers on the basis of the theoretical and empirical research. The following tasks are set for the attaining of the aim:

1) To analyze the contents of the professional competencies of the dance teachers,

2) To analyze the situation at the labor market for the dance teachers and their further education,

3) To establish the improvement principles for the further education of the dance teachers' professional competencies.

\section{Materials and Methods}

Both the theoretical methods (the analysis and modeling of the professional competencies of the dance teachers) and the empirical (survey analyses and processing) research methods have been used in the research. The research implements a professional experience analysis of 15 graduates of the study programme Teacher of the dance and rhythmic at Riga Teacher Training and Educational Management Academy, as well as survey results of 82 Latvia's dance teachers.

By use of R. Garleja's approach to the characterization of the professional competencies, we are of the opinion that this is an ability to fulfill oneself in the framework of the professional functions, by integrating the knowledge and values for achievement of aims in the professional work (Garleja, 2003). The dance teacher's competencies involve knowledge in choreography, pedagogy, psychology; they integrate types of artistic and pedagogical action. S. Vìtola in her Master's paper (Vìtola, 2007) finds that the most crucial feature of the dance teachers' pedagogical action competency is a professional suitability. The professional suitability is divided into the absolute and the relative. The absolute suitability refers to those professions, which require special individual qualities (abilities), but the relative suitability refers to the professions, which can be attained practically by any individual. A. Klauss characterizes it as "the suitability of individual's qualities for the requirements of a definite profession, which are set in order to achieve an appropriate efficiency of the professional action, due to the respective labor market conjunction." (Klauss, 2003).

The profession of the dance teacher, where the competency of the artistic-pedagogical action involves a necessity to acquire, master and implement special abilities, determines a requirement of the absolute professional suitability (Arnold, 2005). It means that the dance teacher's knowledge and skills have to reach such a professional level, which can be assessed as the competence. The 
dance teacher has to develop each individual's abilities - intellectual, physical and emotional, although the dance group usually involves many participants, each of them having a unique individuality (Harman, 2007). Therefore, the dance teacher's task is to discover, encourage and stimulate the individual potential of each dancer. R. Zaharov claims - "all opportunities are given by the nature to the human being, inserted into his/her intuitive abilities. One should only revive, wake them up, if they are asleep. This exactly is one of the choreographer-educationalist's most crucial tasks" (Захаров, 1976).

Yet the dance teacher's professional duties are also to know of dance genres and style specifics, to teach the understanding of the dance culture, to know and to develop the history and traditions of his/her dance group, to carry out educational work (Spalva, 2004). The full-value dance teacher's action is maintained by the abilities of the educationalist:

- To learn;

- To search;

- To think;

- To collaborate;

- To be active;

- To adapt oneself (Šmite, 2004).

The abovementioned characterizes the image of the contemporary dance educationalist and determine types of his/her actions, which are manifested by self-devotion to work, collaboration with colleagues, as well as by the ability to self-reflection and assessment of his/her activities. Taking into consideration the above mentioned, the competency of the dance teacher is characterized by the following:

- Willingness to work with people,

- Interpersonal abilities - friendliness, sense of humor, being interested in people, patience etc.,

- Skill to develop relationships on basis of equality,

- Interest in what he/she teaches to others, and the eagerness to let others master it,

- Flexibility, skills to reach compromises (Lieǵeniece, 2002).

\section{Results}

In Latvia, the further education of the dance teachers is provided traditionally by the further education courses, which are regularly organized and whose content is provided by the State agency Tautas mākslas centrs (Folk Art Centre), which is under the surveillance of the Ministry of Culture, and the Valsts Jaunatnes iniciativu centrs (State Youth Initiative Centre) supervised by the Ministry of Education and Science. The audiences of the further education courses consist of the managers of the dance groups in Latvia. The contents of the courses has been unchanged for ages - the fundamentals of the classical dance, the methodology of the training sessions, the fundamentals of the Latvian dances and other subjects included into the higher education school programme. The dance teachers and the managers of the dance groups are active participants of these further education courses, nevertheless, a lot of the dance teachers are of the opinion that it is only a revision of the higher education school knowledge.

To find out the professional interests of the dance teachers in Latvia, and to construct an appropriate professional development programme for them, in 2006 - 2007, the lecturers and graduates of Riga Teacher Training and Educational Management Academy got involved into the project The further education programme development and piloting for the professional competency improvement of the graduates of the programme of the teacher of the Dance and rhythmic at 
RTTEMA co-financed by the EU. The project was aimed at development of the further education programme, which would suit the dance teachers' interests, would be appropriate for the labor market demands, and objective to the accessible information in the area of the dance pedagogy. The project was implemented pursuing the aim to improve the dance teachers' professional competencies for promoting the further education of competitive dance and rhythmic teachers. The project team involved 15 dance teachers - graduates of RTTEMA from different regions of Latvia. By help of the project team, 82 dance teachers all over Latvia were surveyed. To achieve the set aim, a questionnaire was developed, the surveying of the dance teachers was accomplished, contents of a study course were constructed, and the piloting of the study subjects was carried out at the master-classes and seminars.

When analysing work experience at dance pedagogy, it was found that the respondents have diverse experience at dance pedagogy (expressed in years, Table 1, Figure 1), but the respondents' time spent working at dance pedagogy is arranged quite evenly over the periods of time.

Table 1. Respondent's work experience

Figure 1. Work experience at in dance pedagogy. dance pedagogy, years.

\begin{tabular}{|c|c|c|}
\hline $\begin{array}{c}\text { Number } \\
\text { of years of } \\
\text { the work } \\
\text { experience }\end{array}$ & $\begin{array}{c}\text { Number of } \\
\text { respondents }\end{array}$ & Percentage \\
\hline $1-5$ & 16 & $20 \%$ \\
\hline $6-10$ & 19 & $23 \%$ \\
\hline $11-20$ & 21 & $25 \%$ \\
\hline $21-30$ & 18 & $22 \%$ \\
\hline $31-$ & 8 & $10 \%$ \\
\hline
\end{tabular}

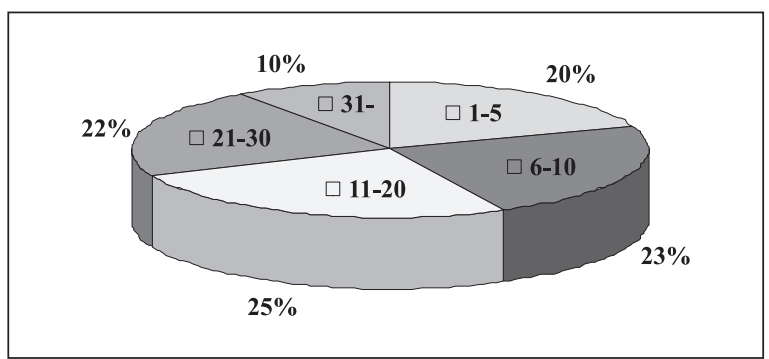

It follows that educationalists with a remarkable time amount spent at work as well as teachers of the younger generation teach dancing in Latvia. This fact confirms that interest in dance is not exhausted, and improvement of dance teachers' competencies is important in Latvia.

The survey revealed that the dance teachers mainly work in the field of folk dances, but some teachers work in several genres (for example, stage dances and dance aerobics or the free style and line dances, Figure 2).

The survey results show that the most required one is the genre of folk dances $83 \%$. It is followed by the free style $-18 \%$ of surveyed dance educationalists teach this dance genre, as well as the classic dance and fashion dance $-13 \%$.

The survey helped to find out the children's and adults' age groups with which the 82 dance teachers work. Most widely represented age group is the primary school $-74 \%$ of the surveyed educationalists teach to this age group, just a little less than the elementary school $-67 \%$ of the surveyed.

Figure 2. Most popular dance genres taught by the surveyed dance educationalists.

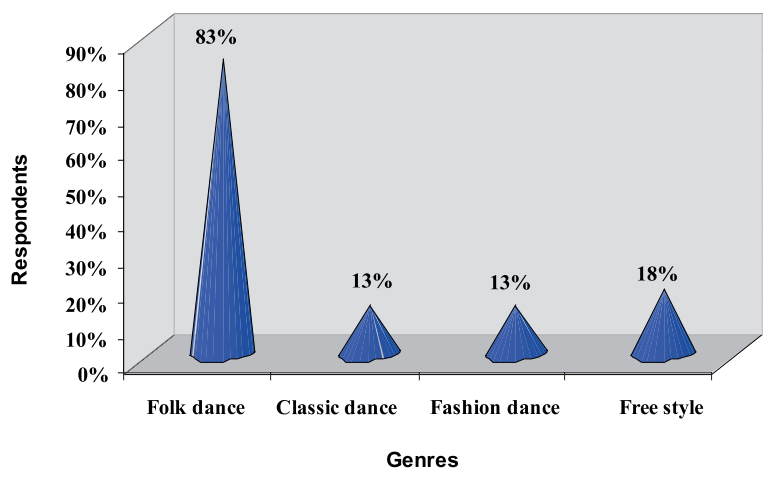


The results of the survey reveal that the dance is taught to all age groups. Since the age group of school children is most widely represented, it can be concluded that dances are mostly taught to children of school age. It turned out that almost all respondents work with dancers of various age (Figure 3).

The survey reveals that dance educationalists

Figure 3. Respondents teach dance to of Latvia wish to improve their knowledge and continue a life-long learning. Scope of fields attracting the respondents is very wide but the dance teachers thought that most important is to improve knowledge in dance teaching methodology, dance analyses, theory, as well as they wish to acquire information on new fields - dance therapy and remedial gymnastics (see Figure 4). various age groups.

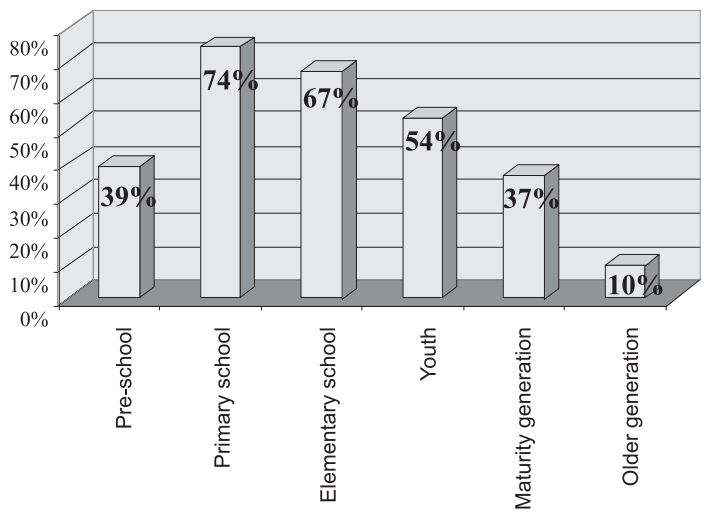

Figure 4. Professional interests of the respondents.

\section{Fields, where the respondents want to improve their knowledge}

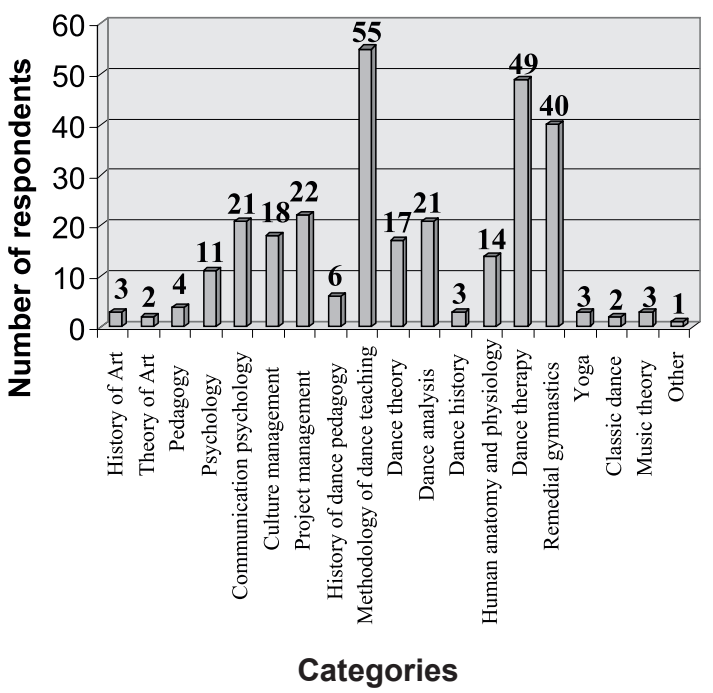

A large group of dance teachers are of the opinion that they should improve also their knowledge in communication psychology, project management and culture management.

By researching of the dance teachers' professional interests, the labor market needs and opportunities, a new model was constructed and piloted for level B further education of the dance teachers in compliance with the requirements set by the Regulations No. 570 by the Cabinet of Ministers of the Republic of Latvia (procedure for professional development of the educators of the general education and the educators of interest-related education, 2007). The developed 
model (consisting of 72 hours) includes the study subjects based on self-experience (Dance teaching methodology), the study subjects based on the experience of others (Dance theory, Dance therapy), implemented the world experience (Communication psychology). The piloting of the established model revealed that such an approach not only increases the professional level of the dance teachers, but also increases the competitiveness of the teachers at the labor market and be demanded there. It was established that the needed fundamental skills of the dance teachers are based on the previously obtained education and self-experience, but the development of the skills and their growth into competencies is provided by the advanced acquisition of the study subjects, cognition of experience of others, implementation of the world experiences (The professional development programme of the dance teachers, 2007).

The analysis of the project materials empirically proves the theoretically set basic principles for the further education of the dance teachers:

1) The existence of self-experience,

2) The analyses of other experiences,

3) The implementation of the world experience.

\section{Conclusions}

By analyzing the dance teachers' competencies, by constructing and piloting the dance teacher competency development model for the further education, it is proved that the subjectcontent structure of the dance teacher professional competencies is constructed by correlation of two components - the subjective and the objective, which is based on the basic principles of the further education (self-experience, other experience, the world experience) and is implemented by the continuous life-long education.

\section{REFERENCES}

1. Arnold P. J. (2005) Some Aesthetics, Education and the Art of Dance. Journal of Aesthetic Education, Vol. 39 No 1 p. 48-64.

2. Bruck A.(2002) Welche Kompetenzen? Anforderungen, Grundlagen und Ueberblick aus antropologischer Perspektive, in Basiskompetenzen. Reihe:7, Praktische Kompetenz, 1.1, [online] www.basiskompetenze.de (19.11.2007)

3. Dance Teachers' Professional Improvement Programme (Deju skolotāju profesionālās pilnveides programma) (2007) Closing document of Project the further education programme development and piloting for the professional competency improvement of the graduates of the programme of the teacher of the Dance and rhythmic at RTTEMA . Rīga: Drukātava, $61 \mathrm{p}$.

4. Garleja R. (2003) Darbs, organizācija un psihologija. Rīga: RaKa, 20 lpp.

5. Gilbert A. G. (2005) Dance Education in the $21^{\text {st }}$ Century: A Global Perspective. Journal of Physical Education Recreation and Dance JOPERD, Vol. 76 No 5 p. 26.

6. Harman R. (2007) Critical Teacher Education in Urban Contexts: Discursive Dance of a Middle School Teacher. Language and Education, Vol. 21, No 1, p. 31-45.

7. Klauss A. (2002) Zinības vadītājam. Rīga: Preses nams, 353 lpp.

8. Lieǵeniece D. (2002) Ievads andragog̀ijā. Rīga: RaKA, 75 lpp.

9. Spalva R. (2007) Development of Dance Composition in Students'Artistic Activities (Dejas kompozīcijas prasmju attīstība studentu mākslinieciskajā darbībā). Promocijas darbs. Rīga: LU, $204 \mathrm{p}$. 
10. Šmite A. (2004) Izglītības iestādes vadība. Part I, Rīga: RaKa, p. 96-97.

11. Tilııla I. (2005) Sociālkultūras mācīšanās organizācijas sistēma. Rīga: Raka, 39 p.

12. Procedure for Professional Development of the Educators of the General Education and the Educators of Interest-Related Education (28 August 2007) Cabinet of Ministers Regulations No 570.

13. Vìtola S. (2007) Deju kolektīva vadītāja kompetenču nozìme mākslinieciskā kolektīva efektīvas darbības nodrošināšanā. Ma;gistra darbs. Rīga: RPIVA, 95 lpp.

14. Захаров Р. (1976) Записки балетмейстера. Москва: Искусство, 69 с.

Asoc. prof. Dr. paed. Rita Spalva

Riga Teacher Training and Educational Management Academy

Address: Andromedas gatve 10-31, Riga, LV-1084, Latvia

Phone: +371 29455831

Fax: +37167808034

E-mail: rita.spalva@,rpiva.lv

Lecturer Mg. sc. soc. Sandra Vìtola

Riga Teacher Training and Educational Management Academy

Address: Brīvības 76-33, Riga, Latvia

Phone: +371 29665246

Fax: +37167808034

E-mail: sandra.vitola@rpiva.lv 